\title{
Adsorption Removal of Lead Ions by Acacia tortilis Leaves: Equilibrium, Kinetics and Thermodynamics
}

\author{
M. A. Ackacha and L. A. Elsharif
}

\begin{abstract}
In this research, the Acacia tortilis leaves was utilized as an adsorbent material for the removal of lead ions from aqueous solution. Batch experiments were used to predict the adsorption capacity of lead ions onto Acacia tortilis leaves. Different parameters affecting the adsorption process were tested including initial $\mathrm{pH}$ of adsorbate, adsorbent dose, contact time and contact temperature. Three kinetic models, including first order, pseudo-second order and intra-particle diffusion were used to analyze the adsorption process. The adsorption process was investigated using Langmuir and Freundlich isotherm models. The maxima adsorption capacities were 704.8, $632.3,437$ and 332 at $303,313,323$ and $323 \mathrm{~K}$, respectively. Thermodynamic parameters such as gibbs free energy, enthalpy and entropy were calculated to predict the nature of the adsorption. Langmuir and Freundlich models were applied to describe the adsorption isotherm.
\end{abstract}

Index Terms-Lead ions, adsorption, acacia tortilis, langmuir isotherm, thermodynamic parameters.

\section{INTRODUCTION}

Heavy metals such as lead released into the environment due to the industrial activate during the recent years such as batteries and steel industries discharge various concentrations of lead into water media [1], [2]. Because of the high toxicity of lead, its removal from water environment is very important. Lead can accumulates mainly in bones, kidney, muscles and brain. Leads cause too much health problems for instance hypertension, brain damage and kidney damage [3]. Even at low concentration of lead present in waste water, may cause hepatitis and anemia [3]. The recommended levels of lead in waste water as reported by Environmental Protection Agency (EPA) and Water Health Organization (WHO) are 0.05 and $0.01 \mathrm{mg} / 1$, respectively [3].

There are various techniques for reducing heavy metals from water environment including chemical precipitation, membrane filtration, ion exchange, liquid extraction or electrodialysis [4]. Most of these techniques are extremely expensive or inefficient and take too much time [5]. Among these techniques, adsorption using a low cost agriculture material was used due to the presence of polar functional groups such as aldehyde, ketones, phenolic acid and carboxylic in their molecular structure [6]. The following agriculture materials were used in literatures as natural adsorbents: date stones [7], almond green hull [8], olive cake

Manuscript submitted August 7, 2012; revised September 12, 2012.

M. A. Ackacha is with Chemistry Department, Faculty of Science, Sebha University, Libya (e-mail: ackacha57@yahoo.com).

L. A. Elsharif is a chemist with the Secondary school, Samno, Sebha, Libya. ash [9], phragmites australis [10], walnut shell [11], rice hull and sawdust [12], peanut shells [13], orange peel [14], crab shell [15] and tea wastes [16].

In this article, the ability of Acacia tortilis leaves to remove lead ions from aqueous environment has been studied. Several parameters affecting the adsorption process were studied including initial $\mathrm{pH}$ of adsorbate, adsorbent dose, contact time and contact temperature. The adsorption isotherm as well as kinetic adsorption and thermodynamic adsorption have been investigated.

\section{EXPERIMENTAL}

\section{A. Reagents and Equipments}

All chemical reagents grade were obtained from Merck, Germany. A pH meter, model 3505 was delivered from Jenway Felsted, Dunmow, Essex C.46 SLB, United Kingdom. The shaker of orbital shaker model number 501 was purchased from Stuart Scientific, United Kingdom.

\section{B. Adsorbent Preparation}

Acacia tortilis leaves were used in this investigation. They were washed several times with distilled water to remove undesirable materials, filtered, dried at $93{ }^{\circ} \mathrm{C}$ for 2 hours, then grounded to a very fine powdered $(50-125 \mu \mathrm{m})$. The obtained fine powder was stored in plastic container to be used later without any pretreatment.

\section{Lead Solution Preparation}

2 grams of lead acetate was dissolved in one liter of distilled water and used as a stock solution. The work solutions were prepared by dilution of the stock solution to required volume. The $\mathrm{pH}$ of the work solutions was controlled using $0.01 \mathrm{M} \mathrm{HCl}$ and $0.01 \mathrm{M} \mathrm{NaOH}$.

\section{Batch Adsorption}

Batch experiments were carried out by shaking a stopper flasks contain $100 \mathrm{ml}$ lead ion solution of specific concentration and $0.04 \mathrm{~g}$ of Acacia tortilis leaves at $400 \mathrm{rpm}$ for desirable time, temperature and initial $\mathrm{pH}$. The initial lead concentration as well as final lead concentration after adsorption was calculated by titration with EDTA using xylenol orange as indicator. The amount of adsorbed lead ions onto Acacia tortilis leaves was determined using mass balance equation [3]:

$$
q_{e}=\frac{\left(C_{o}-C_{e}\right) \times V}{W}
$$

where $\mathrm{Co}$ and $\mathrm{Ce}$ are the initial and final concentration of $\mathrm{Pb}$ 
(II) ions solution (mg/l), $\mathrm{V}$ is the volume of lead ion solution (l) and $\mathrm{W}$ is the weight of Acacia tortilis leaves ( $\mathrm{g})$.

\section{RESUlTS AND DISCUSSION}

\section{A. Effect of Initial $\mathrm{pH}$ of $\mathrm{Pb}$ (II) Ion Solutions on} Adsorption Capacity.

The initial $\mathrm{pH}$ of the heavy metal is very important factor in any adsorption process [17]. As shown in Fig. 1, there is too less removal of lead ion from aqueous solution at initial $\mathrm{pH}$ lower than 2.9 may be due to high concentration of $\mathrm{H}+$ ion. There is a gradual increase of adsorption capacity with increase initial $\mathrm{pH}$. The maximum adsorption capacity was observed at initial $\mathrm{pH} 4$. At $\mathrm{pH}$ higher than 4, lead ions may be precipitated and adsorption studies could not be performed.

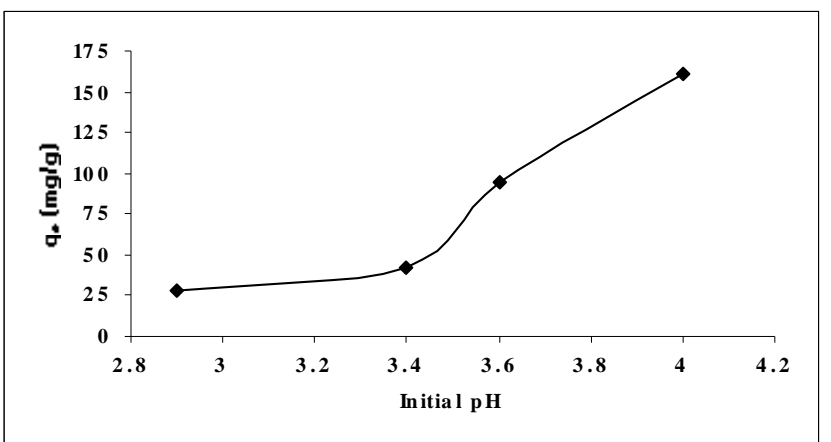

Fig 1. Effect of initial $\mathrm{pH}$ on adsorption capacity at adsorption conditions: contact temperature, $30{ }^{\circ} \mathrm{C}$; concentration of lead ions solution, $300 \mathrm{mg} / \mathrm{l}$; contact time, $2 \mathrm{~h}$; Acacia tortilis leaves dose, $0.4 \mathrm{~g} / \mathrm{l}$; agitation speed, $400 \mathrm{rpm}$ and particles diameter of Acacia tortilis leaves, 90-125 $\mu \mathrm{m}$.

\section{B. Effect of Adsorbent Dose on Adsorption Capacity}

Fig. 2 shows the effect of adsorbent doses on adsorption capacity of lead ions onto Acacia tortilis leaves. When the adsorbent dose was increased from 0.3 to $1 \mathrm{~g} / 1$, the adsorption capacity decreases from 575.3 to $142.2 \mathrm{mg} / \mathrm{g}$. This phenomena is mainly due to overlapping of the adsorption sites because of overcrowding of the adsorbent particles and also may be due to the competition among lead ions onto the Acacia tortilis leaves [18].

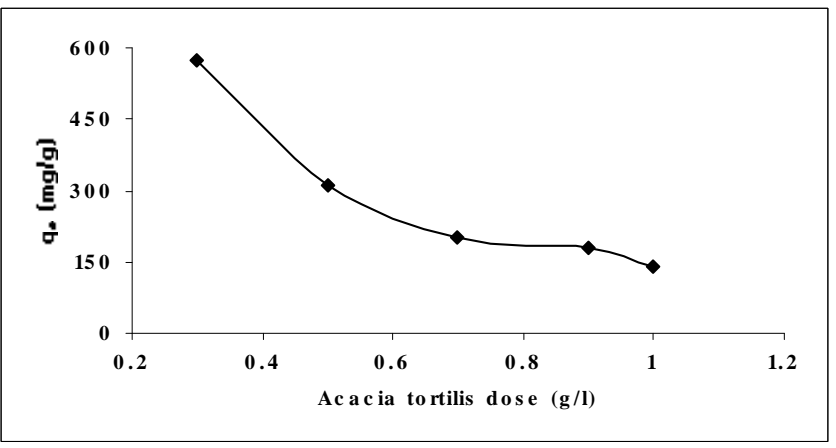

Fig 2. Effect of adsorbent dose on adsorption capacity at adsorption conditions: contact temperature, $30{ }^{\circ} \mathrm{C}$; concentration of lead ions solution, $300 \mathrm{mg} / \mathrm{l}$; contact time, $2 \mathrm{~h}$; initial $\mathrm{pH}$, 4, agitation speed, $400 \mathrm{rpm}$ and particles diameter of Acacia tortilis leaves, 90-125 $\mu \mathrm{m}$.

\section{Effect of Contact Time on Adsorption Capacity}

Effect of contact time on adsorption capacity of lead is presented in Fig. 3. The obtained results explained that, the adsorption capacity increases with increase of contact time and reach the equilibrium state after 60 minute. These results explained also that, the adsorption capacity depend on the concentration of the lead ions.

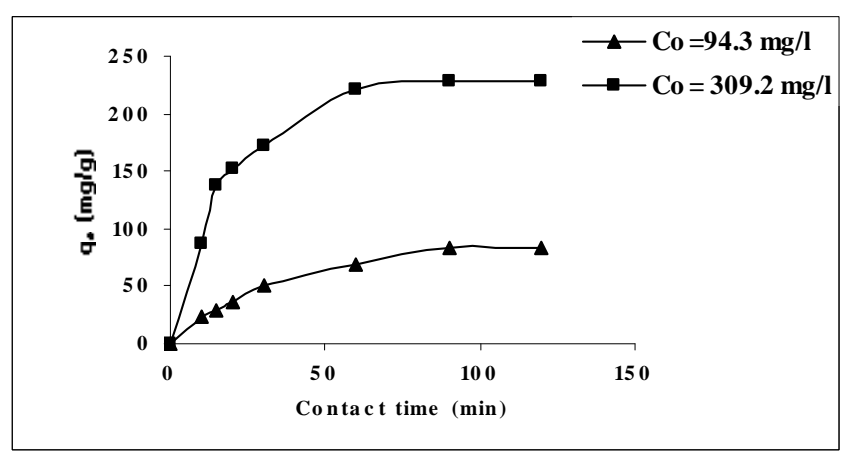

Fig. 3. Effect of contact time on adsorption capacity at adsorption conditions: contact temperature, $30 \mathrm{oC}$; concentration of lead ions solution, $300 \mathrm{mg} / \mathrm{l}$; initial pH, 4; Acacia tortilis leaves dose, $0.4 \mathrm{~g} / \mathrm{l}$; agitation speed, $400 \mathrm{rpm}$ and particles diameter of Acacia tortilis leaves, 90-125 $\mu \mathrm{m}$.

\section{Kinetic Studies}

In order to understand the adsorption kinetic of lead (II) ions, three kinetic models include first-order, pseudo-second-order and intraparticle diffusion, have been applied for the experimental data. The intergrated form of the Lagergren [19], pseudo-second-order [19] and Weber \& Morris [20] equations are expressed as:

$$
\begin{gathered}
\log \left(q_{e}-q_{t}\right)=\log q_{e}-\frac{K_{1}}{2.303} t \\
\frac{t}{q_{t}}=\frac{1}{K_{2} q_{e}{ }^{2}}+\frac{1}{q_{e}} t \\
q_{t}=k_{p} t^{1 / 2}+C
\end{gathered}
$$

where $\mathrm{K} 1$ is the first-order constant, $\mathrm{K} 2$ is the pseudo-second-order constant and $\mathrm{Kp}$ is the intra-particle diffusion constant. qe calculated and qt are adsorption capacity at equilibrium and at any time, respectively. $\mathrm{C}$ give an indication about the thickness of the boundary layer.

$\mathrm{K}_{1}\left(\mathrm{~min}^{-1}\right)$ values can be determined from the slop of the linear plots of $\log \left(\mathrm{q}_{\mathrm{e}}-\mathrm{q}_{\mathrm{t}}\right)$ versus $\mathrm{t}$ (Fig. 4), $\mathrm{K}_{2}$ (g/mg. min) was calculated from the linear plots of $\frac{t}{q_{t}}$ against $t$ (Fig. 5).

$\mathrm{q}_{\mathrm{e}}$ calculated (mg/g) values for both first- order and pseudo second order were calculated respectively from the linear plots of $\log \left(\mathrm{q}_{\mathrm{e}}-\mathrm{q}_{\mathrm{t}}\right)$ versus $\mathrm{t}$ (Fig. 4) and linear plots of $\frac{t}{q_{t}}$ against t (Fig. 5). 


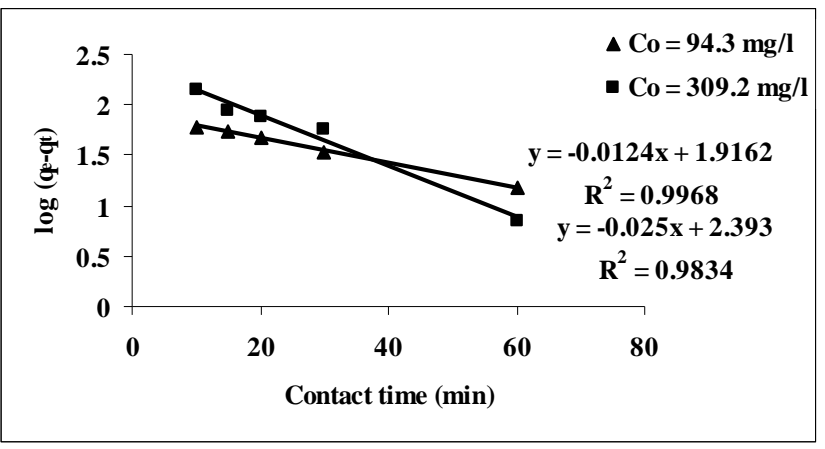

Fig. 4. Lagergren plots for the adsorption of lead ions onto Acacia tortilis leaves, first-order model.

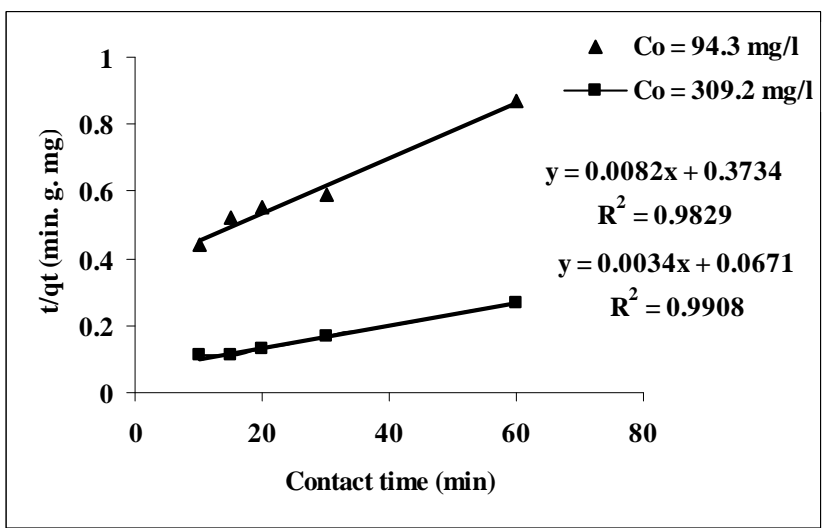

Fig. 5. Pseudo-second-order kinetic plots for the adsorption of lead ions onto Acacia tortilis leaves.

The constants $\mathrm{K}_{1}$ and $\mathrm{K}_{2}, \mathrm{q}_{\mathrm{e}}$ experimental $\left(\mathrm{q}_{\mathrm{e}}\right.$ exp.) and $\mathrm{q}_{\mathrm{e}}$ calculated $\left(\mathrm{q}_{\mathrm{e}}\right.$ calc.) and liner correlation coefficient $\left(\mathrm{R}^{2}\right)$ for the first order and pseudo second order reaction kinetics are summarized in Table I. In first order reaction kinetic, calculated values of $\mathrm{q}_{\mathrm{e}}$ are closer to $\mathrm{q}_{\mathrm{e}}$ experimental values more than pseudo second-order. Therefore, the adsorption kinetic could well be explained by first order kinetic.

TABLE I: COMPARISON OF ADSORPTION RATE CONSTANTS, EXPERIMENTAL AND CALCULATED ADSORPTION CAPACITIES VALUES FOR FIRST AND SECOND ORDER REACTION KINETICS OF LEAD IONS ONTO ACACIA TORTILIS

\begin{tabular}{ccccccccc}
\multicolumn{4}{c}{ LEAVES } \\
\hline \hline $\mathrm{C}_{\mathrm{o}}$ & $\mathrm{q}_{\mathrm{e}}$ & \multicolumn{3}{c}{ First order } & \multicolumn{3}{c}{ Pseudo second order } \\
$(\mathrm{mg} / \mathrm{l})$ & exp. & $\mathrm{K}_{1}$ & $\mathrm{q}_{\mathrm{e}}$ calc. & $\mathrm{R}^{2}$ & \multicolumn{1}{c}{$\mathrm{K}_{2}$} & $\mathrm{q}_{\mathrm{e}}$ calc. & $\mathrm{R}^{2}$ \\
\hline 94.3 & 82.5 & 0.03 & 82.5 & 0.9968 & 0.00018 & 122 & 0.9829 \\
309.2 & 227 & 0.06 & 247 & 0.9834 & 0.000017 & 294 & 0.9908 \\
\hline \hline
\end{tabular}

According to the equation 4, a plot of qt versus t1/2 (Fig. 6) should be straight line when adsorption mechanism follows the intraparticle diffusion process. The values of $\mathrm{Kp}$ and $\mathrm{C}$ were obtained respectively from the slop and intercept of the plot of qt versus $t 1 / 2$. These values as well as the correlation coefficient $\left(\mathrm{R}^{2}\right)$ are listed in Table II. The high values of $\mathrm{R} 2$ proved that, the adsorption mechanism of lead ions onto Acacia tortilis leaves follows the intraparticle diffusion process. Because of the deviation of the curves from the origin point, intraparticle diffusion cannot be accepted as the only rate-determining step for the adsorption of lead ions onto Acacia tortilis leaves [20].

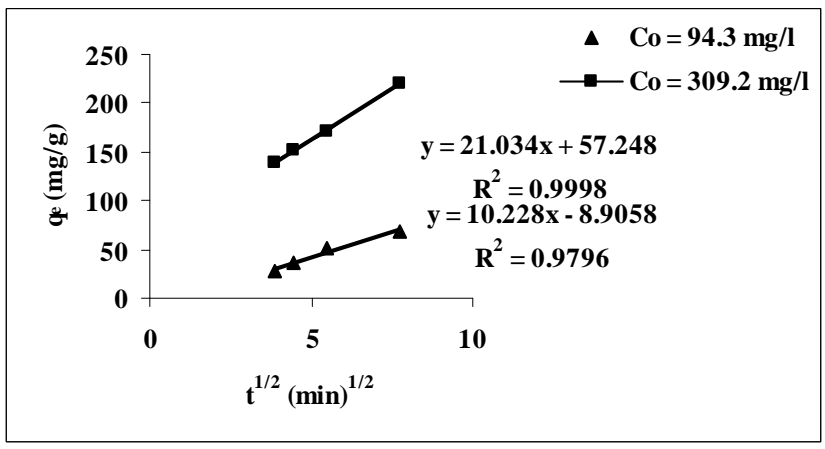

Fig. 6. Intraparticle diffusion plots for the adsorption of lead ions onto Acacia tortilis leaves.

TABLE II: RATE PARAMETERS OF INTRAPARTICLE DIFFUSION OF LEAD IONS ONTO ACACIA TORTILIS LEAVES

\begin{tabular}{cll}
\hline \hline $\mathrm{C}_{\mathrm{o}}(\mathrm{mg} / \mathrm{l})$ & $\mathrm{C}$ & $\mathrm{R}^{2}$ \\
\hline 94.3 & 8.9 & 0.9796 \\
309.2 & 57.2 & 0.9998 \\
\hline \hline
\end{tabular}

\section{E. Adsorption Isotherm Studies}

The adsorption isotherm of lead ions onto Acacia tortilis leaves at different contact temperatures are presented in Fig. 7.

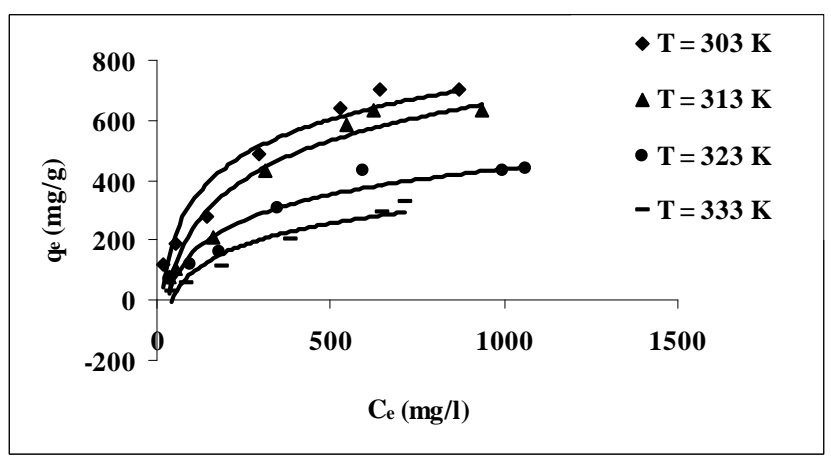

Fig.7. Adsorption of lead ions onto Acacia tortilis leaves at different contact temperatures.

Several isotherm equations are available and two important isotherms are applied in this work include Langmuir [21] and Freundlich [22] isotherms. The adsorption isotherms were obtained for contact temperatures $303,313,323$ and $333 \mathrm{~K}$, while keeping all other parameters constants at optimum conditions.

The Langmuir equation expressed as follows:

$$
\frac{C_{e}}{q_{e}}=\frac{1}{q_{\max } \cdot b}+\frac{1}{q_{\max }} C_{e}
$$

where $\mathrm{q}_{\max }(\mathrm{mg} / \mathrm{g})$ and $\mathrm{b}(\mathrm{l} / \mathrm{mg})$ are related to the maximum adsorption capacity and energy of adsorption, respectively. These constants were obtained from the plots of $\frac{C_{e}}{q_{e}}$ versus $\mathrm{C}_{\mathrm{e}}$ (Fig. 8) and used to calculate the Langmuir constant $\left(\mathrm{K}_{\mathrm{L}}\right)$ according to the following equation:

$$
K_{L}=q_{\max } \times b
$$


The Langmuir model can be expressed in terms of an equilibrium parameter $\left(\mathrm{R}_{\mathrm{L}}\right)$ given by the following equation:

$$
R_{L}=\frac{1}{1+b \times C_{O}}
$$

The values of $R_{L}$ give an idea about the shape of isotherm (Table III) [23]. The $\mathrm{R}_{\mathrm{L}}$ values at different temperatures are illustrated in Table IV. The values lie between 0 and 1 indicating that, the adsorption of lead ions onto Acacia tortilis leaves at different temperatures is favorable.

TABLE III: RELATION BETWEEN R $\mathrm{L}_{\mathrm{L}}$ VALUES AND TYPE OF ISOTHERM

\begin{tabular}{ll}
\hline \hline$R_{L}$ value & Type of isotherm \\
\hline$R L>1$ & Unfavorable \\
$R L=1$ & Linear \\
$0<R_{L}<1$ & Favorable \\
$R_{L}=0$ & Irreversible \\
\hline \hline
\end{tabular}

TABLE IV: $\mathrm{R}_{\mathrm{L}}$ VALUEES BASED ON LANGMUIR EQUATION

\begin{tabular}{lllll}
\hline \hline & \multicolumn{5}{c}{$\mathrm{R}_{\mathrm{L}}$ values } \\
$\mathrm{C}_{\mathrm{o}}(\mathrm{mg} / \mathrm{l})$ & $303 \mathrm{~K}$ & $313 \mathrm{~K}$ & $323 \mathrm{~K}$ & $333 \mathrm{~K}$ \\
\hline 75.80 & 0.01310 & 0.01320 & 0.01320 & 0.01320 \\
113.8 & 0.00875 & 0.00876 & 0.00876 & 0.00878 \\
227.6 & 0.00437 & 0.00438 & 0.00438 & 0.00439 \\
441.9 & 0.00231 & 0.00258 & 0.00226 & 0.00226 \\
720.7 & 0.00138 & 0.00138 & 0.00138 & 0.00139 \\
815.6 & 0.00122 & 0.00122 & 0.00122 & 0.00122 \\
1126 & 0.00884 & 0.00089 & 0.00089 & 0.00089 \\
\hline \hline
\end{tabular}

The Freundlich equation can be expressed as follows:

$$
\log q_{e}=\log K_{F}+\frac{1}{n} \operatorname{loq} C_{e}
$$

where $\mathrm{K}_{\mathrm{F}}$ and $\mathrm{n}$ are the Freundlich constants which determined from the plots of $\log c_{e}$ versus $\log q_{e}$ (Fig. 9).

Table $\mathrm{V}$ and Table 6 presented respectively, the isotherm parameters for both Langmuir and Frundlich models. It is noted from these Tables that, the linear coefficients $\left(\mathrm{R}^{2}\right)$ of the Freundlich isotherm model showed a better fit to the present work. The values of $\mathrm{n}(1-10)$, indicating that, the adsorption of $\mathrm{Pb}$ (II) ions onto Acacia tortilis leaves is favorable [20].

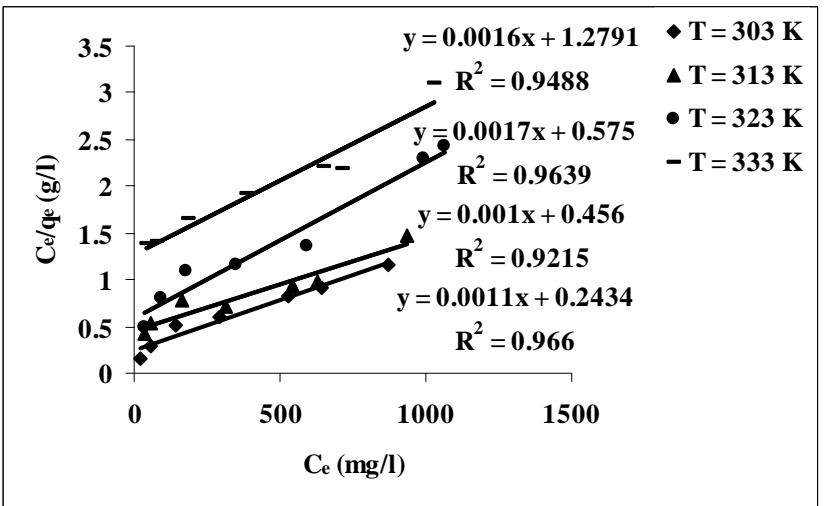

Fig. 8. Langmuir adsorption isotherm of lead ions onto Acacia tortilis leaves at different contact temperatures.

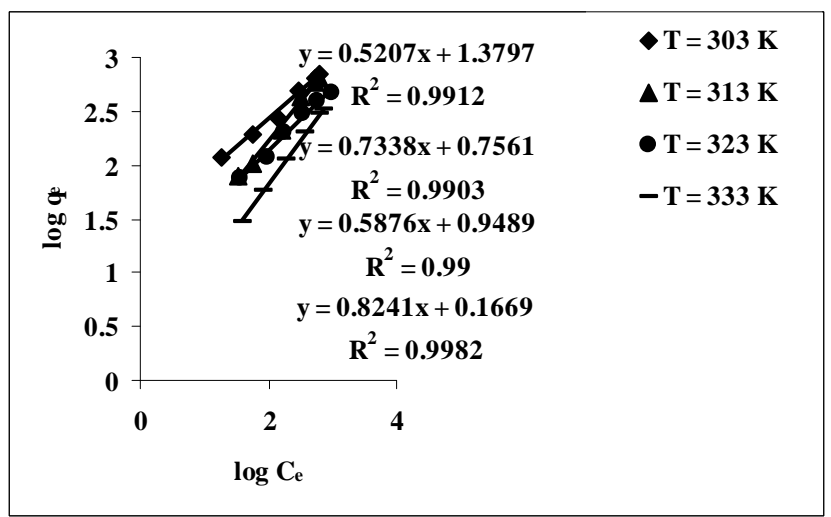

Fig. 9. Freundlich adsorption isotherm lead ions onto Acacia tortilis leaves at different contact temperatures.

TABLE V: THE LANGMUIR ISOTHERM PARAMETERS AT DIFFERENT TEMPERATURES

\begin{tabular}{lcccl}
\multicolumn{5}{c}{ TEMPERATURES } \\
\hline \hline $\mathrm{T}(\mathrm{K})$ & $\mathrm{q}_{\max }$ exp. & $\mathrm{b}$ & $\mathrm{K}_{\mathrm{L}}$ & $\mathrm{R}^{2}$ \\
& $(\mathrm{mg} / \mathrm{g})$ & $(1 / \mathrm{mg})$ & $(1 / \mathrm{g})$ & \\
\hline 303 & 704.8 & 0.0045 & 4.11 & 0.9660 \\
313 & 632.3 & 0.0022 & 2.20 & 0.9215 \\
323 & 437.0 & 0.0031 & 1.76 & 0.9639 \\
333 & 332.0 & 0.0012 & 0.75 & 0.9488 \\
& & & & \\
\hline
\end{tabular}

TABLE 6: THE FREUNDLICH ISOTHERM PARAMETERS AT DIFFERENT

\begin{tabular}{llcc}
\multicolumn{4}{c}{ TEMPERATURES } \\
\hline \hline \multicolumn{4}{c}{ Freundlich isotherm } \\
$\mathrm{T}(\mathrm{K})$ & $\mathrm{K}_{\mathrm{F}}$ & $\mathrm{n}$ & $\mathrm{R}^{2}$ \\
\hline 303 & 23.97 & 1.97 & 0.9912 \\
313 & 5.70 & 1.36 & 0.9903 \\
323 & 8.90 & 1.70 & 0.9900 \\
333 & 1.47 & 1.21 & 0.9982 \\
\hline \hline
\end{tabular}

\section{F. Thermodynamic Studies}

The type of the adsorption can be determined through the quantities of thermodynamic parameters such as Gibbs free energy $\Delta G^{\circ}$, standard enthalpy $\Delta H^{\circ}$ and entropy change $\Delta S^{\circ}$ for the adsorption of lead ions onto the surface of Acacia tortilis leaves. These parameters are given in Table 6 . $\Delta G^{\circ}$ was calculated using the following equation:

$$
\Delta G^{\circ}=-R T \ln K_{L}
$$

where $R$ is the universal gas constant $(8.314 \mathrm{j} / \mathrm{mol} \mathrm{k})$ $\Delta H^{0}$ and $\Delta S^{0}$ were calculated respectively from the slop and intercept of the plots of $\frac{1}{T}$ versus $\ln \mathrm{K}$ (Fig. 10) using the Van't Hoff equation [24]:

$$
\ln k=\frac{\Delta S^{\circ}}{R}-\frac{\Delta H^{\circ}}{R T}
$$

The negative values of $\Delta G^{\circ}$ showed that, the adsorption process was spontaneous thermodynamically. However, the decrease of the values of $\Delta G^{\circ}$ with increase temperatures 
proved that, the adsorption was not favorable at higher temperatures. The negative value of $\Delta H^{\circ}$ indicated the exothermic nature of the adsorption process. The negative value of $\Delta S^{\circ}$ suggest the decrease of randomness through the interface during the adsorption of lead ions onto the surface of Acacia tortilis leaves.

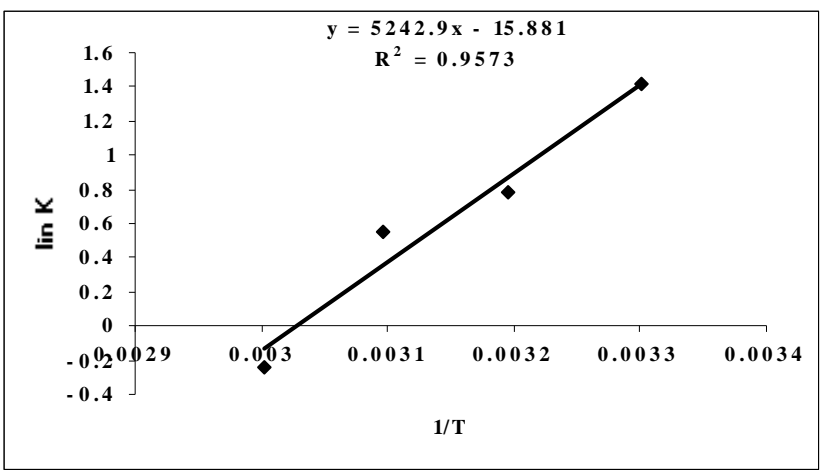

Fig. 10. Plot of $\operatorname{lnK}$ vs. 1/T

TABLE VI: THERMODYNAMIC PARAMETERS FOR THE ADSORPTION OF LEAD IONS ONTO ACACIA TORTILIS LEAVESTHE FREUNDLICH ISOTHERM PARAMETERS AT DIFFERENT TEMPERATURES

\begin{tabular}{|c|c|c|c|c|c|}
\hline \multicolumn{4}{|c|}{$\begin{array}{c}\Delta G^{\circ} \\
(\mathrm{Kj} / \mathrm{mol} . \mathrm{K})\end{array}$} & \multirow[t]{2}{*}{$\begin{array}{c}\Delta H^{\circ} \\
(\mathrm{Kj} / \mathrm{mol} . \mathrm{K})\end{array}$} & \multirow[t]{2}{*}{$\begin{array}{c}\Delta S^{\circ} \\
(\mathrm{Kj} / \mathrm{mol} . \mathrm{K})\end{array}$} \\
\hline $303 \mathrm{k}$ & $313 \mathrm{~K}$ & $323 \mathrm{~K}$ & $333 \mathrm{~K}$ & & \\
\hline-3.55 & -2.04 & -1.48 & -0.62 & -43.56 & -0.13 \\
\hline
\end{tabular}

\section{G. Comparison of Adsorption Capacity of Acacia tortilis Leaves with Other Agriculture Adsorbents}

In order to test the performance of Acacia tortilis leaves as effective adsorbent for removal of lead ions from aqueous solutions, a comparison with other adsorbents was made (Table 7). All adsorbents showed lower removal of lead ions from aqueous solutions than Acacia tortilis leaves [24], [25].

TABLE VII: ADSORPTION CAPACITY OF LEAD IONS BY DIFFERENT AGRICULTURE ADSORBENTS

\begin{tabular}{llc}
\hline \hline Adsorbent & $\mathrm{pH}$ & $\mathrm{q}_{\mathrm{e}}(\mathrm{mg} / \mathrm{g})$ \\
\hline Oil mill residue & 5.6 & 21.65 \\
Cocoa shells & 2 & 6.2 \\
Nile rose plant powder & 5 & 27.4 \\
Palm shell activated carbon & 5 & 95.5 \\
Modefied peanut sawdust & 4 & 29.1 \\
Pseudomonas aeraginose & 5.5 & 68.4 \\
Grap stalks & 5.5 & 49.7 \\
Rice husk & 5.5 & 4 \\
Hazelnat shell & 6.6 & 1.78 \\
Syzgium Cumin L & 6 & 32.47 \\
C. inophyllum & 4 & 34.51 \\
This study & 4 & 704.8 \\
\hline \hline
\end{tabular}

\section{CONCLUSION}

The results can be summarized as follows:

1) The adsorption capacity was initial $\mathrm{pH}$ dependent and the optimum $\mathrm{pH}$ was 4 .

2) The adsorption of lead ions onto the Acacia tortilis leaves was very fast within $15 \mathrm{~min}$ and reached equilibrium after $60 \mathrm{~min}$.
3) Freundlich adsorption isotherm was better fitted for adsorption of lead ions than Langmuir adsorption isotherm.

4) The process is exothermic in nature due to the negative value of $\Delta \mathrm{H}^{\mathrm{o}}$.

5) At temperatures ranged from $303-333 \mathrm{~K}$, the system was spontaneous and the spontaneously decrease as the temperature increase.

6) The randomness is decrease through the interface during the adsorption of lead ions onto the surface of Acacia tortilis leaves.

7) Kinetically, the adsorption kinetic could well be explained by first order kinetic.

\section{REFERENCES}

[1] R. Muhammad, N. Raziya, A. H. Muhammad, M. A. Tariq and R. Khalil, "Pb (II) biosorption from hazardous aqueous streams using Gossypium hirsutum (Cotton) waste biomass," Journal of Hazardous Materials, vol. 161, pp. 88-94, March 2008.

[2] A. R. Kul and H. Koyuncu, "Adsorption of $\mathrm{Pb}$ (II) ions from aqueous solution by native and activated bentonite: Kinetic, equilibrium and thermodynamic study," Journal of Hazardous Materials, vol. 179, pp. 332-339, March 2010.

[3] H. Lalhruaitluanga, K. Jayaram, M. N. V. Prasad, and K. K. Kumar, "Lead (II) adsorption from aqueous solutions by raw and activated charcoals of Melocanna baccifera Roxburgh (bamboo)-A comparative study," Journal of Hazardous Materials, vol. 175, pp. 311-318, October 2010.

[4] Q. Li, J. Zhai, W. Zhang, M. Wang, and J. Zhou, "Kinetic studies of adsorption of $\mathrm{Pb}$ (II), $\mathrm{Cr}$ (III) and $\mathrm{Cu}$ (II) from aqueous solution by sawdust and modified peanut husk," Journal of Hazardous Materials, vol. 141, pp. 163-167, July 2006.

[5] Y. Jiang, H. Pang, and B. Liao, "Removal of copper (II) ions from aqueous solution by modified bagasse," Journal of Hazardous Materials, vol. 164, pp. 1-9, August 2008.

[6] F. Qin, B. Wen, X. Q. Shan, and Y. N. Xie, "Mechanisms of competitive adsorption of $\mathrm{Pb}, \mathrm{Cu}$ and $\mathrm{Cd}$ on peat," Environmental Pollution, vol. 144, pp. 669-680, December 2005.

[7] N. M. Haimour and S. Emeish, "Utilization of date stones or production of activated carbon using phosphoric acid," Waste Management, vol. 26, pp. 651-660, October 2005

[8] A. Ahmadpour, M. Tahmasbi, T. Rohani, and J. Amel Besharati, "Rapaid removal of cobalt ion from aqueous solutions by almond green hull," Journal of Hazardous Materials, vol. 166, pp. 925-930, December 2008.

[9] Z. Elouear, J. Bouzid, N. Boujelben, M. Feki, and A. Montiel, "The use of exhausted olive cake ash (EOCA) as a low cost adsorbent for the removal of toxic metal ions from aqueous solutions," Fuel, vol. 87, pp. 2582-2589, February 2008

[10] B. Southichak, K. Nakano, M. Nomura, N. Chiba, and O. Nishimura, "phragmites australis: A novel biosorbent for the removal of heavy metals from aqueous solution," Water Research, vol. 40, pp. 2295-2302, April 2006.

[11] M. Zabihi, A. Ahmadpour, and A. Haghighi Asi, "Removal of mercury from water by carbonaceaous sorbents derived from walnut shell," Journal of Hazardous Materials, vol. 167, pp. 230-236, December 2008.

[12] F. Asadi, H. Shariatmadari, and N. Mirghaffari, "Modification of rice husk and sawdust sorptive characteristics for remove heavy metals from synthetic solutions and wastewater," Journal of Hazardous Materials, vol. 154, pp. 451-458, October 2007.

[13] K. Wilson, H. Yang, C. W. Seo, and W. E. Marshall, "Select metal adsorption by activated carbon made from peanut shells," Bioresource Technology, vol. 97, pp. 2266-2270, December 2005.

[14] X. Li, Y. Tang, X. Cao, D. Lu, F. Luo, and W. Shao, "Preparation and evolution of orange peel cellulose adsorbents for effective removal of cadmium, zinc, cobalt and nickel," Colloid and surfaces A, vol. 317, 512-521, November 2007.

[15] D. S. Kim, "The removal by crab shell of mixed heavy metal ions in aqueous solution," Bioresource Technology, vol. 87, pp. 355-357, October 2002.

[16] B. M. W. P. K Amarasinghe, and R. A. Williams, "Tea waste as a low cost adsorbent for the removal of $\mathrm{Cu}$ and $\mathrm{Pb}$ from wastewater," 
Chemical Engineering Journal, vol 132, 299-309, January 2007.

[17] M. Madhava, A. Ramesh, G. Purna Chandra Rao, and K. Seshaiah, "Removal of copper and cadmium from the aqueous solutions by activated carbon derived from ceiba pentandra hulls" Journal of Hazardous Materials B, vol. 129, pp. 123-129, September 2005.

[18] A. R. Ifikhar, H. N. Bhatti, M. A. Hanif, and R. Nadeem, "Kinetic and thermodynamic aspects of $\mathrm{Cu}$ (II) and $\mathrm{Cr}$ (III) removal from aqueous solutions using rose waste biomass," Journal of Hazardous Materials, vol. 161, pp. 941-947, April 2008.

[19] R. Nadeem, M. H. Nasir, and M. S. Hanif, "Pb (II) sorption by acidically modified cicer arientinum biomass," Chemical Engineering Journal, vol. 150, pp.40-48, December 2009.

[20] W. S. Wan Ngah and K. M. Hanafiah, "Adsorption of copper on rubber (Hevea brasiliensis) leaf powder: Kinetic, equilibrium and thermodynamic studies," Biochemical Engineering Journal, vol. 39, pp. 521-530, November 2007.

[21] Y. S. Ho and A. E. Ofomaja, "Biosorption thermodynamics of cadmium on coconut copra meal as biosorbent," Biochemical Engineering Journal, vol. 30, pp. 117-123, February 2006.

[22] M. A. Ackacha, "Removal of Zn (II) ions from aqueous solution by new adsorbent: Calligonum comosum," International Journal of Chemical Environment and Engineering, vol. 1, no. 1, pp. 18-22, July 2010.

[23] P. Chakravarty, N. S Sarma, and H. P Sarma, "Removal of lead (II) from aqueous solution using heartwood of Areca catecha powder," Desallination, vol. 256, pp. 16-21, March 2010.

[24] O. S. Lawal, A. R. Sanni, I. A. Ajaui, and O. O. Rabiu, "Equilibrium, thermodynamic and kinetic studies for the biosorption of aqueous lead
(II) ions onto the seed husk of calaphyllum inophyllum," Journal of Hazardous Materials, vol. 177, pp. 829-835, January 2010.

[25] G. Issabaycva, M. K. Aroua, and N. M. N. Sulaiman, "Removal of lead from aqueous solutions on palam shell activated carbon" Bioresource Technology, vol. 97, pp. 2350-2355, November 2005.

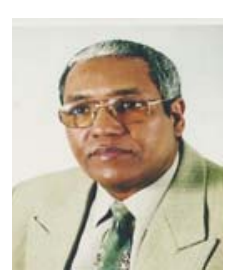

Mohamed Abduelrahman Ackacha was born in Samno, Libya. B.Sc from Chemistry Department, Faculty of science, Tripoli University, Libya. M. Sc from Faculty of Chemistry, Micaway Kopernik University, Torun, Poland. Ph.D in analytical Chemistry from Analytical Chemistry Department, Faculty of Chemistry, Warsaw University of Technology, Warsaw, Poland.

The experience in the field of removal of heavy metals and dyes from aqueous media using agriculture materials.

At the current time, some researches include the use of agriculture adsorbents treated with natural activators were tried for heavy metals removal from aqueous solutions, reuse of some agriculture adsorbents for heavy metals removal from aqueous solutions and removal of heavy metals from hard aqueous media by agriculture adsorbents.

$\mathrm{He}$ is Associate Prof. of analytical chemistry and supervised about ten M. $\mathrm{Sc}$ thesis and two M. Sc work under preparation. 